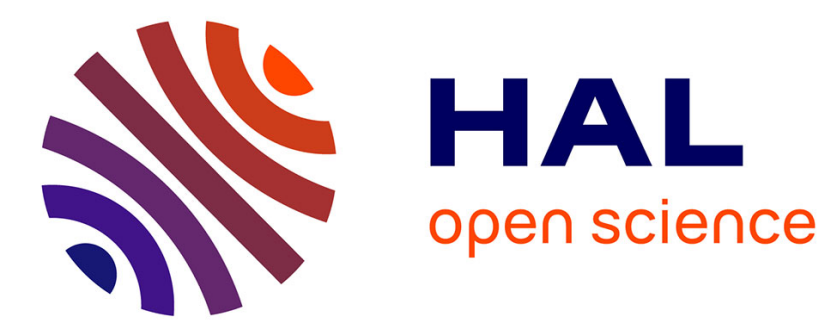

\title{
Chemistry of Dimetallaoctaborane(12) with Chalcogen-Based Borate Ligands: Obedient versus Disobedient Clusters
}

Chandan Nandi, Sourav Kar, Mohammad Zafar, Ketaki Kar, Thierry Roisnel, Vincent Dorcet, Sundargopal Ghosh

\section{To cite this version:}

Chandan Nandi, Sourav Kar, Mohammad Zafar, Ketaki Kar, Thierry Roisnel, et al.. Chemistry of Dimetallaoctaborane(12) with Chalcogen-Based Borate Ligands: Obedient versus Disobedient Clusters. Inorganic Chemistry, 2020, 59 (6), pp.3537-3541. 10.1021/acs.inorgchem.0c00122 . hal02533162

HAL Id: hal-02533162

https://hal-univ-rennes1.archives-ouvertes.fr/hal-02533162

Submitted on 12 May 2020

HAL is a multi-disciplinary open access archive for the deposit and dissemination of scientific research documents, whether they are published or not. The documents may come from teaching and research institutions in France or abroad, or from public or private research centers.
L'archive ouverte pluridisciplinaire HAL, est destinée au dépôt et à la diffusion de documents scientifiques de niveau recherche, publiés ou non, émanant des établissements d'enseignement et de recherche français ou étrangers, des laboratoires publics ou privés. 


\title{
Chemistry of Dimetallaoctaborane(12) with Chalcogen-based Borate Ligands: Obedient vs Disobedient Clusters
}

\author{
Chandan Nandi, ${ }^{\dagger}$ Sourav Kar, ${ }^{\dagger}$ Mohammad Zafar, ${ }^{\dagger}$ Ketaki Kar, ${ }^{\dagger}$ Thierry Roisnel, Vincent Dorcet, $^{\ddagger}$ \\ and Sundargopal Ghosh*,†
}

\author{
†Department of Chemistry, Indian Institute of Technology Madras, Chennai 600036, India \\ ‡Université de Rennes, CNRS, Institut des Sciences Chimiques de Rennes, UMR 6226, F-35000 Rennes, France
}

KEYWORDS: Cobalt, Cluster, Growth, Octaborane, Chalcogen

Supporting Information Placeholder

\begin{abstract}
Reactions of dimetallaoctaboranes(12) $\left[\left(\mathrm{Cp}^{*} \mathrm{M}\right)_{2} \mathrm{~B}_{6} \mathrm{H}_{10}\right]\left(\mathrm{M}\right.$ : Co (1) or $\left.\mathrm{Rh}(2) ; \mathrm{Cp}^{*}=\eta^{5}-\mathrm{C}_{5} \mathrm{Me}_{5}\right)$ with different chalcogen sources, such as $\mathrm{Li}_{2}\left[\mathrm{BH}_{2} \mathrm{E}_{3}\right]$ and $\mathrm{Li}\left[\mathrm{BH}_{3} \mathrm{EPh}\right](\mathrm{E}=\mathrm{S}$, Se or Te), led to two unique reaction outcomes. For example, formation of 10-vertex nido$\left[\left(\mathrm{Cp}^{*} \mathrm{M}\right)_{2} \mathrm{~B}_{6} \mathrm{E}_{2} \mathrm{H}_{6}\right](3: \mathrm{M}=\mathrm{Co}, \mathrm{E}=\mathrm{S} ; \mathbf{4}: \mathrm{M}=\mathrm{Co}, \mathrm{E}=\mathrm{Se} ; \mathbf{5}: \mathrm{M}=$ $\mathrm{Co}, \mathrm{E}=\mathrm{Te} ; \mathbf{6}: \mathrm{M}=\mathrm{Rh}, \mathrm{E}=\mathrm{Se}$ ) from compounds 1-2 is a typical representation of a cluster growth reaction, while the formation of arachno- $\left[\left(\mathrm{Cp}^{*} \mathrm{Co}\right)_{2} \mathrm{~B}_{6} \mathrm{H}_{9}(\mathrm{EPh})\right]$ (E: S (9); Se (10) or Te (11)) is a rare method that yielded arachno clusters keeping the core geometry identical. Formation of arachno-9-11 is an unique method that converts disobedient cluster $\mathbf{1}$ to obedient 9-11. Further, the reactivity of nido-4 with various metal carbonyls presented sequential cluster growth reactions, which afforded 11-vertex nido- $\left[\left(\mathrm{Cp}^{*} \mathrm{Co}\right)_{2} \mathrm{~B}_{6} \mathrm{Se}_{2} \mathrm{H}_{6}\left\{\mathrm{Fe}(\mathrm{CO})_{3}\right\}\right]$ (7) and 13-vertex fused closo-[(Cp*Co $\left.{ }_{2} \mathrm{~B}_{6} \mathrm{Se}_{2} \mathrm{H}_{6}\left\{\mathrm{Ru}_{3}(\mathrm{CO})_{8}\right\}\right]$ (8). The core geometry of nido-7 is uncommon and very similar to that of $\left[\mathrm{C}_{2} \mathrm{~B}_{9} \mathrm{H}_{11}\right]^{2-}$ with a unique open pentahapto coordinating 5-membered face.
\end{abstract}

The chemistry associated with polyhedral borane, ${ }^{1}$ carborane, $1 \mathrm{~b}, 2$ metallaborane, ${ }^{1 b, 3}$ and metallacarborane ${ }^{4}$ clusters have been strengthening the field of organometallic chemistry for many years. Higher nuclearity boron containing clusters or a combination of boron, carbon or metal, have widespread applications starting from the field of polymers, nanomaterials, ceramics and boron-neutron-capture-therapy.1,4,5 Apart from their extensive applications, they have been extremely useful to investigate the unique bonding and very large size electronic structures. ${ }^{1 c, 6}$ Since 1950 Lipscomb, 1a Hawthorne, ${ }^{\text {4a }}$ Welch, ${ }^{7} \mathrm{Xie}^{8}$ and us $^{9}$ reported various single-cage clusters enriched with boron, carbon and transition metals however, a unified scheme for the synthesis of polyhedra of specified composition and geometry from molecular synthons is an arduous synthetic task.

Construction of large polyhedra from small clusters is usually undefined and typically uncontrolled. ${ }^{10}$ Beginning with the founding work of Hawthorne followed by many main group pioneers, the polyhedron-expansion chemistry has witnessed several synthetic challenges.1-4,7-10 For example, a large number of higher nuclearity clusters made of transition metals are synthesized by the fusion of smaller building blocks such as tetrahedral, trigonal bipyramid and octahedral.11 However, this methodology led to the formation of fused clusters. ${ }^{11}$ On the other hand, many higher nuclearity single cage metallaborane clusters are synthesized using pentamethylcyclopentadienyl metal chlorides and monoborane reagents, for example, $\mathrm{LiBH}_{4} \cdot \mathrm{THF}, \mathrm{BH} 3 \cdot \mathrm{THF}$, and $\mathrm{BH}_{3} \cdot \mathrm{SMe}_{2}$, which are also uncontrolled. ${ }^{12,13}$ As a result, search for a unified synthetic strategy become of interest.

In our previous study, we have explored the reactivity of pentamethylcyclopentadienyl based metal halides with various chalcogen-based borate ligands, such as, $\mathrm{Li}\left[\mathrm{BH}_{2} \mathrm{E}_{3}\right]$ or $\mathrm{Li}\left[\mathrm{BH}_{3} \mathrm{EPh}\right]$, which led to the formation of several metallaheteroboranes, albeit in a uncontrolled pathway. ${ }^{14,15}$ Although uncontrolled, the isolation of many interesting molecules from these chalcogen-based ligands tempted us to investigate the same reactions with preformed metallaborane clusters. As a result, we pursued this chemistry with octaborane(12) analogues [(Cp* M) $\left.{ }_{2} \mathrm{~B}_{6} \mathrm{H}_{10}\right]$ (M: Co (1) or Rh (2)). ${ }^{16,17}$ Surprisingly, the different chalcogen-based ligands react with octaborane(12) analogues in distinct fashions. Herein, we present some practical synthetic routes for the isolation of two classes of clusters.
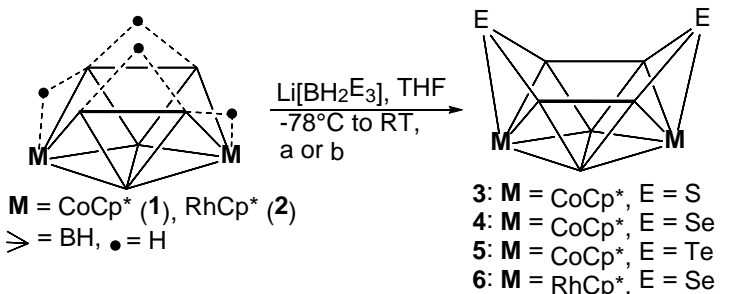

Scheme 1. Syntheses of nido-3-6. (a): RT, $16 \mathrm{~h}$ (for 3, 4 and 6), (b): $80^{\circ} \mathrm{C}, 16 \mathrm{~h}$ (for 5 ).

Reaction of $\left[\left(\mathrm{Cp}^{*} \mathrm{Co}\right)_{2} \mathrm{~B}_{6} \mathrm{H}_{10}\right], \mathbf{1}$ with $\mathrm{Li}\left[\mathrm{BH}_{2} \mathrm{E}_{3}\right](\mathrm{E}=\mathrm{S}$, Se or $\mathrm{Te}$ ) led to the formation of compounds 3-5 (Scheme 1), which were characterized by ${ }^{1} \mathrm{H},{ }^{11} \mathrm{~B}$, and ${ }^{13} \mathrm{C}$ NMR and IR spectroscopy as well as mass spectrometry. The ${ }^{1} \mathrm{H}\left\{{ }^{11} \mathrm{~B}\right\}$ NMR of 3-5 suggest the existence of single $\mathrm{Cp}^{*}$ environments appearing at $\delta=1.66,1.66$, and $1.72 \mathrm{ppm}$ respectively. The ${ }^{11} \mathrm{~B}\left\{{ }^{1} \mathrm{H}\right\}$ NMR spectrum of $\mathbf{3}$ displays two resonances at $\delta=31.8$ and $22.1 \mathrm{ppm}$ with an intensity ratio of 2:4. The ${ }^{11} \mathrm{~B}\left\{{ }^{1} \mathrm{H}\right\}$ NMR spectra of both $\mathbf{4}$ and $\mathbf{5}$ also show two chemical shifts similar to that of $\mathbf{3}$. The mass spectra of compounds 
3-5 show molecular ion peaks at $m / z \quad 523.1509[\mathrm{M}]^{+}$, $618.0316[\mathrm{M}]^{+}$and $715.0158[\mathrm{M}]^{+}$respectively that indicate the formation of identical core with different chalcogen atoms, i.e., for 3 (S), 4 (Se) and 5 (Te). Although both ${ }^{1} \mathrm{H}\left\{{ }^{11} \mathrm{~B}\right\}$ and ${ }^{11} \mathrm{~B}\left\{{ }^{1} \mathrm{H}\right\}$ NMR spectra of $\mathbf{3 - 5}$ suggest the formation of symmetric clusters, these spectroscopic data were not sufficient enough to identify the core geometries of 3-5. A clear explanation eluded us until the single crystal X-ray structure analyses of them were carried out.

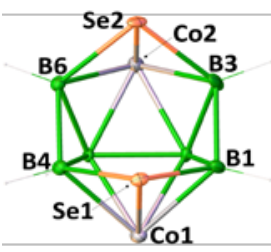

(a)

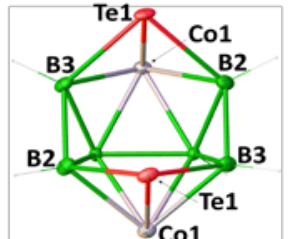

(b)

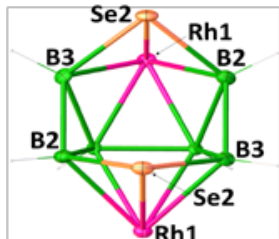

(c)
Figure 1. Molecular structures and labelling diagrams of nido4 (a), nido-5 (b) and nido-6 (c). Cp* attached to metals are omitted for clarity.

The crystal structures of 3-5 correspond to 10-vertex open dicobaltaheteroboranes [(Cp*Co) $\left.{ }_{2} \mathrm{~B}_{6} \mathrm{E}_{2} \mathrm{H}_{6}\right](\mathrm{E}=\mathrm{S}(3)$, Se (4) and $\mathrm{Te}(\mathbf{5})$ ). All the clusters 3-5 are isostructural and isoelectronic with nido-decaborane(14). They can be viewed as 64 cluster valence electron species, which have 12 skeletal electron pairs (SEP). In terms of electron input to cluster, the $\left\{\mathrm{Cp}^{*} \mathrm{Co}\right\}$ unit is isoelectronic with $\{\mathrm{BH}\}$ unit, whereas chalcogen atom is a source of 4 electrons. The average B-B bond distances of nido-3-5 are in the normal range, established for the metallaboranes. ${ }^{11 b, 16,17}$ Consistent with the NMR spectra of nido-3-5, the single-crystal X-ray structure analyses also specify the existence of symmetry planes.

One of the unique features of the formation of decaborane analogues nido-3-5 from octaborane(12) analogue $\mathbf{1}$ is the direct insertion of two chalcogen atoms that expand the cluster from 8 to 10 -vertex. In an order to expand this chemistry to other metals, we have carried out the reaction of $\left[(\mathrm{Cp} * \mathrm{Rh})_{2} \mathrm{~B}_{6} \mathrm{H}_{10}\right]$ with $\mathrm{Li}\left[\mathrm{BH}_{2} \mathrm{Se}_{3}\right]$ that afforded yellow solid 6. The ${ }^{1} \mathrm{H}\left\{{ }^{11} \mathrm{~B}\right\}$ NMR of 6 shows chemical shift at $\delta=1.81 \mathrm{ppm}$, which indicates the presence of one kind of $\mathrm{Cp}^{*}$ environment. ${ }^{11} \mathrm{~B}\left\{{ }^{1} \mathrm{H}\right\}$ NMR spectra display two resonances at $\delta=21.8$ and $21.3 \mathrm{ppm}$ with a relative ratio of $4: 2$. The mass spectrum shows a molecular ion peak at $m / z 704.9850$ that corresponds to the molecular formula $\mathrm{Rh}_{2} \mathrm{~B}_{6} \mathrm{Se}_{2} \mathrm{C}_{20} \mathrm{H}_{36}$. Thus, a similar NMR pattern of 6 and 3-5 along with the mass spectrometric data confirm the composition of 6 as $\left[\left(\mathrm{Cp}^{*} \mathrm{Rh}\right)_{2} \mathrm{~B}_{6} \mathrm{Se}_{2} \mathrm{H}_{6}\right]$. In order to confirm the spectroscopic assignments of $\mathbf{6}$, the solidstate X-ray analysis was carried out. As shown in Figure 1(c), the X-ray analysis revealed 6 as the diselenorhodaborane analogue of nido-3-5. The average B-B, Rh-Se and Rh-B bond distances of 6 of $1.81 \AA, 2.42 \AA$ and $2.20 \AA$ respectively are comparable with reported related rhodaheteroboranes. ${ }^{17,18}$

While comparing the molecular orbitals of the $\mathrm{Cp}$ analogue of nido-3-5, it was observed that the HOMO-LUMO energy gap is decreased while changing the chalcogen atoms from $\mathrm{S} \rightarrow \mathrm{Te}$ (Table S1). On the other hand, changing the metal from Co to $\mathrm{Rh}$, the HOMO-LUMO energy gap increases (Table S1). The HOMO of nido-4 is mainly localized on d-orbitals of both metal centres (Figure S56). Whereas, the HOMO-2 is localized on dorbitals of metals and p-orbitals of both the Se atoms. A similar situation has also been observed for nido-3 and nido-5 in HOMO-2 (Figures S55 and S57).
The directed p-orbitals of the Se atoms of nido-4 in HOMO2 show its donating ability. As a result, we have explored its reactivity with metal carbonyls aiming further cluster growth reaction. As a result, we have carried out the room temperature reaction of $\left[\left(\mathrm{Cp}^{*} \mathrm{Co}\right)_{2} \mathrm{~B}_{6} \mathrm{Se}_{2} \mathrm{H}_{6}\right]$ (4) with $\left[\mathrm{Fe}_{2}(\mathrm{CO})_{9}\right]$, which yielded brown solid 7 (Scheme 2). The ${ }^{1} \mathrm{H}\left\{{ }^{11} \mathrm{~B}\right\}$ NMR spectrum of 7 shows peak at $\delta=1.66 \mathrm{ppm}$, which corresponds to single $\mathrm{Cp}^{*}$ environments. The ${ }^{11} \mathrm{~B}\left\{{ }^{1} \mathrm{H}\right\}$ NMR spectrum shows four chemical shifts at $\delta=36.9,27.5,23.7$ and $13.6 \mathrm{ppm}$. The mass spectrum shows molecular ion peak at 756.9607. As the spectroscopic data was not enough to predict the structure, we have performed single crystal X-ray structural analysis. As shown in Figure S5, the solid-state X-ray analysis of $\mathbf{7}$ shows as 11-vertex nido-[(Cp*Co $\left.)_{2} \mathrm{~B}_{6} \mathrm{Se}_{2} \mathrm{H}_{6}\left\{\mathrm{Fe}(\mathrm{CO})_{3}\right\}\right]$. The open face of nido-7 is made of a distorted pentagon Fe5-Se2-B5-B4$\mathrm{Se} 1$ and isoelectronic with $\left[\mathrm{C}_{2} \mathrm{~B}_{9} \mathrm{H}_{11}\right]^{2-}$.

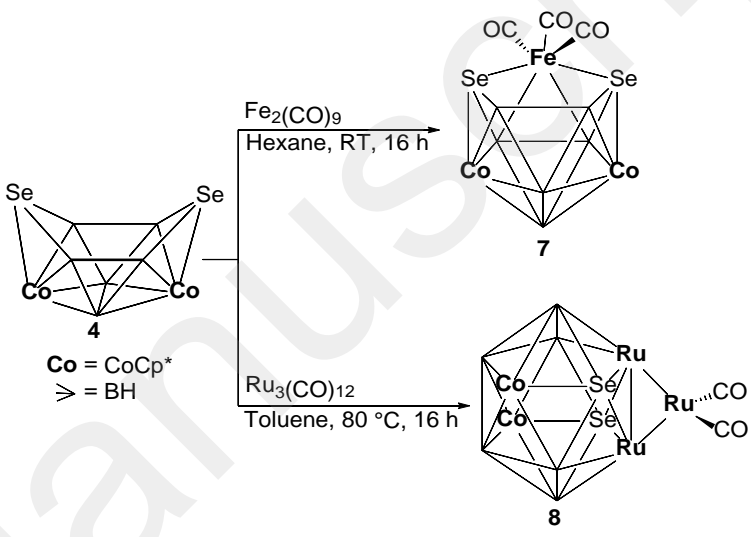

Scheme 2. Syntheses of nido-7 and closo-8 $\left(\mathbf{R u}=\mathrm{Ru}(\mathrm{CO})_{2}\right)$.

One of the interesting features of the pentagon face of nido-7 is the presence of more polarized bonds as compared to $\left[\mathrm{C}_{2} \mathrm{~B}_{9} \mathrm{H}_{11}\right]^{2-}$. Furthermore, the HOMO-14 of nido-7 has porbitals on Se atoms which are tilted towards the centre of the pentagon (Figure S59). As a result, one can envisage that nido7 can further be capped by 2-electron main group or metal fragments to form 12-vertex closo-icosahedral. Hence, we have carried out the reactions of nido-7 both with [ $\left.\mathrm{Fe}_{2}(\mathrm{CO})_{9}\right]$ and $\left[\mathrm{Ru}_{3}(\mathrm{CO})_{12}\right]$ under thermolytic conditions. Although the objective of isolating a closo-cluster was not accomplished from the thermolysis reaction of nido-7 with [Fe $\left.2(\mathrm{CO})_{9}\right]$, nido4 with $\left[\mathrm{Ru}_{3}(\mathrm{CO})_{12}\right]$ yielded closo$\left[\left(\mathrm{Cp}^{*} \mathrm{Co}\right)_{2} \mathrm{~B}_{6} \mathrm{Se}_{2} \mathrm{H}_{6}\left\{\mathrm{Ru}_{3}(\mathrm{CO})_{8}\right\}\right]$ (8), which is a blend of icosahedron $\left\{\mathrm{Co}_{2} \mathrm{Ru}_{2} \mathrm{~B}_{6} \mathrm{Se}_{2}\right\}$ and a triangle $\left\{\mathrm{Ru}_{3}\right\}$.

The ${ }^{11} \mathrm{~B}\left\{{ }^{1} \mathrm{H}\right\}$ NMR spectrum of closo-8 shows two resonances appearing at $\delta=39.4$ and $3.9 \mathrm{ppm}$ and the ${ }^{1} \mathrm{H}$ NMR spectrum shows one chemical shift at $\delta=1.73$ ppm due to $\mathrm{Cp}^{*}$ protons. The mass spectrum shows molecular ion peak at $1144.7386[\mathrm{M}]^{+}$. The solid-state X-ray structure of closo-8 (Figure S6) may be considered as a fusion of an icosahedron $\left\{\mathrm{Co}_{2} \mathrm{Ru}_{2} \mathrm{~B}_{6} \mathrm{Se}_{2}\right\}$ and a triangle $\left\{\mathrm{Ru}_{3}\right\}$ units, which are fused by $\mathrm{Ru}$-Ru edge. The number of cluster valence electrons required for this fused 13-vertex cluster is $104,{ }^{19}$ which is achieved from the available cluster valence electrons of closo-8.

In order to examine the reactivity of $\mathrm{Li}\left[\mathrm{BH}_{3} \mathrm{EPh}\right](\mathrm{E}=\mathrm{S}$, Se or $\mathrm{Te}$ ) with respect to a similar reaction outcome from $\mathbf{1}$, we have carried out the reactions of preformed cobaltaborane $\mathbf{1}$ with $\mathrm{Li}\left[\mathrm{BH}_{3} \mathrm{EPh}\right]$ (Scheme 3). To our surprise, based on the NMR and other spectroscopic data, the reaction led to a different type of clusters 9-11. The ${ }^{1} \mathrm{H}$ NMR spectrum of 9 shows chemical shift at $\delta=1.67 \mathrm{ppm}$ indicating one kind of $\mathrm{Cp}^{*}$ 
environment. In addition to that, it shows two peaks at $\delta=-$ 3.86 and -21.94 ppm may be due to the presence of B- $H$-B and Co- $H$-B protons respectively. The NMR spectroscopic pattern for $\mathbf{1 0}$ and $\mathbf{1 1}$ are alike to that of $\mathbf{9}$. As the spectroscopic data along with the mass spectrometric data were not enough to provide the structure of them, we have performed the single crystal X-ray analysis for 9-10. The solid-state X-ray structure of 10 (Figure S8) shows that one of the bridging B- $H$-B hydrogens of $\mathbf{1}$ is substituted by bridging $\{\mathrm{SePh}\}$ moiety generating 10. Whereas for 9 and 11, the bridging $\mathrm{B}-H-\mathrm{B}$ hydrogen of 1 is substituted by bridging $\{\mathrm{SPh}\}$ and $\{\mathrm{TePh}\}$ units respectively. As bridging $\{\mathrm{EPh}\}$ fragments $(\mathrm{E}=\mathrm{S}$, Se or Te) provide 3 cluster bonding electrons to clusters 9-11, the SEP counts for them amount to 11 . Therefore, 9-11 can be considered as arachno clusters.

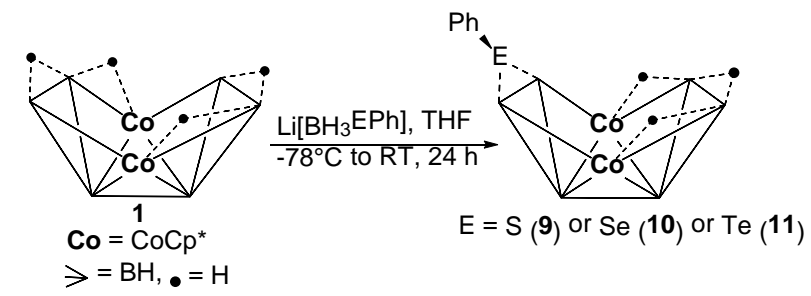

Scheme 3. Syntheses of arachno-9-11.

Molecular orbital analysis of compound $\mathbf{1}$ and arachno-911 using bp86/def2-svp was carried out that established that the HOMO-LUMO energy gap for $\mathbf{1}$ is moderately higher as compared to arachno-9-11. Further, it was observed that the gap between HOMO-LUMO decreased while moving from $\mathrm{S} \rightarrow$ Te (Table S1). The frontier molecular orbitals of arachno9-11 show that the HOMOs are mainly localized on $\mathrm{d}_{\mathrm{z}}{ }^{2}$ orbitals of two cobalt centers and the B-B bonds, which are connected to the exo-\{EPh\} fragments. Further, it was observed that part of HOMO-18 of arachno-9 is comprised of porbitals of two B and one S atom, which are delocalized over BBS ring (Figure S61). An analogous bonding situation has also been observed for arachno-10 and arachno-11 in HOMO15 (Figure S62) and HOMO-14 (Figure S63) respectively. The above bonding scenario was further supported by Wiberg Bond Indices (Table S2).

Electron counting rules, along with isolobal analogy, provided a solid foundation to evaluate the structure of a wide range of polyhedral clusters of varying nuclearity.6,20-22 However, the well-established cluster electron-counting rules often encountered challenges due to the rapid expansion of the field of polyhedral boron and main-group chemistry. ${ }^{23}$ For example, Wade's rule predicts octaborane(12) is of formal nido- $\mathrm{B}_{\mathrm{n}} \mathrm{H}_{\mathrm{n}+4}$ constitution. However, the core geometry is of arachno type, which can be generated by the removal of two adjacent vertices from 10-vertex closo-bicapped square antiprism. ${ }^{24}$ These clusters are categorized as 'disobedient'.23 Many such types of metallaborane analogues of octaborane(12) including $\mathbf{1}$ and $\mathbf{2}$ are belong to disobedient clusters due to the presence of lesser number of SEP than 11. One of the $\mathrm{B}-\mathrm{H}$-B bridging hydrogens in $\mathbf{1}$ has been replaced by three electron $\{\mathrm{EPh}\}$ fragment that yielded arachno-9-11. Thus, one may envisage the conversion of $\mathbf{1}$ to arachno-9-11 as disobedient to obedient clusters.

In summary, this paper describes several sequential cluster growth reactions of $\mathbf{1}$ or $\mathbf{2}$ by means of $\left[\mathrm{LiBH}_{2} \mathrm{E}_{3}\right]$ and metal carbonyls. Using a two-step procedure, we were able to synthesize closo-icosahedral cluster from 1. In addition, we have further established a unique method to transform diso- bedient clusters to obedient one substituting one of the bridging $\mathrm{B}-H-\mathrm{B}$ hydrogens by three electrons $\{\mathrm{EPh}\}$ fragment. We strongly believe that the novel methods reported in this paper for the synthesis of polyhedral boron clusters from $\mathbf{1}$ in a sequential and controlled fashion are unique.

\section{ASSOCIATED CONTENT}

Supporting Information

Experimental procedures, additional experimental data, computational data, and crystallographic data (CIF) for compounds 3-11. The Supporting Information is available free of charge at http://pubs.acs.org.

\section{AUTHOR INFORMATION}

Corresponding Author

*E-mail: sghosh@iitm.ac.in

Funding Sources

Council of Scientific \& Industrial Research, New Delhi, India (Project 01(2939)/18/emr-ii)

Notes

The authors declare no competing financial interests.

\section{ACKNOWLEDGMENT}

C.N. and K.K. thank DST-INSPIRE for fellowships. S.K. and M.Z. thank IIT Madras for fellowships. The computational facility, IIT Madras is gratefully acknowledged.

\section{REFERENCES}

(1) (a) Lipscomb, W. N. Boron Hydrides; Dover Publications Inc., Mineola, NY, 2012. (b) Grimes, R. N. In Comprehensive Organometallic Chemistry II; Abel, E. W., Stone, F. G. A., Wilkinson, G., Eds.; Pergamon: Oxford, U.K., 1995; Vol. 1, p 373. (c) Schleyer, P. v. R.; Najafian, K.; Mebel, A. M. The Large closo-Borane Dianions, $\mathrm{B}_{\mathrm{n}} \mathrm{H}_{\mathrm{n}}{ }^{2-}(\mathrm{n}=13-17)$ Are Aromatic, Why Are They Unknown? Inorg. Chem. 1998, 37, 67656772.

(2) (a) Zhang, J.; Xie, Z. Recent Progress in the Chemistry of Supercarboranes. Chem. Asian J. 2010, 5, 1742-1757. (b) Yu, W.-B.; Cui, P.F.; Gao, W.-X.; Jin, G.-X. B-H activation of carboranes induced by late transition metals. Coor. Chem. Rev. 2017, 350, 300-319. (c) Zhang, X.; Yan, H. Transition metal-induced B-H functionalization of $o$ carborane. Coor. Chem. Rev. 2019, 378, 466-482.

(3) Roy, D. K.; Ghosh, S.; Halet, J. -F. Beyond the icosahedron: The quest for high-nuclearity supraicosahedral in metallaboranes. J. Cluster. Sci., 2014, 25, 225-237.

(4) (a) Hawthorne, M. F.; Dunks, G. B.; McKown, M. M. Probable formation of 13-atom polyhedral complexes containing $\mathrm{B}_{10} \mathrm{C}_{2} \mathrm{H}_{12}{ }^{2-}$ and cobalt. J. Am. Chem. Soc. 1971, 93, 2541-2543. (b) Saxena, A. K.; Hosmane, N. S. Recent advances in the chemistry of carborane metal complexes incorporating d- and f-block elements. Chem. Rev. 1993, 93, 1081-1124.

(5) Tietze, L. F.; Griesbach, U.; Bothe, U.; Nakamura, H.; Yamamoto, Y. Novel Carboranes with a DNA Binding Unit for the Treatment of Cancer by Boron Neutron Capture Therapy. ChemBioChem 2002, 3, 219-225.

(6) (a) Jemmis, E. D.; Balakrishnarajan, M. M.; Pancharatna, P. D. Electronic Requirements for Macropolyhedral Boranes. Chem. Rev. 2002, 102, 93-144. (b) Jemmis, E. D. Overlap control and stability of polyhedral molecules closo-Carboranes. J. Am. Chem. Soc. 1982, 104, 7017-7020.

(7) Burke, A.; Ellis, D.; Giles, B. T.; Hodson, B. E.; Macgregor, S. A.; Rosair, G. M.; Welch, A. J. Beyond the Icosahedron: The First 13- Vertex Carborane. Angew. Chem., Int. Ed. 2003, 42, 225-228.

(8) Deng, L.; Zhang, J.; Chan, H.-S.; Xie, Z. Synthesis and Structure of 14- and 15-Vertex Ruthenacarboranes. Angew. Chem. Int. Ed. 2006, 45, 4309-4313. 
(9) (a) Roy, D. K.; Bose, S. K.; Anju, R. S.; Mondal, B.; Ramkumar, V.; Ghosh, S. Boron Beyond the Icosahedral Barrier: A 16-Vertex Metallaborane. Angew. Chem. Int. Ed. 2013, 52, 3222-3226. (b) Roy, D. K.; Mondal, B.; Shankhari, P.; Anju, R. S.; Geetharani, K.; Mobin, S. M.; Ghosh, S. Supraicosahedral Polyhedra in Metallaboranes: Synthesis and Structural Characterization of 12-, 15- and 16-Vertex Rhodaboranes. Inorg. Chem. 2013, 52, 6705-6712.

(10) Grimes, R. N. Cluster forming and cage fusion in metallacarborane chemistry. Coord. Chem. Rev. 1995, 143, 71-96.

(11). (a) Hosmane, N. S.; Grimes, R. N. Transition-metal-promoted oxidative fusion with carborane and borane anions. Synthesis of $\mathrm{C}_{4} \mathrm{~B}_{n}$ ( $n=8-11$ ) carborane systems in the presence of $\mathrm{B}_{5} \mathrm{H}_{8}{ }^{-}$and $\mathrm{B}_{3} \mathrm{H}_{8}$ - ions Inorg. Chem. 1980, 19, 3482-3487. (b) Zafar, M.; Kar, S.; Nandi, C.; Ramalakshmi, R.; Ghosh, S. Cluster Fusion: Face-fused Macropolyhedral Tetracobaltaboranes. Inorg. Chem. 2019, 58, 47-51. (c) Bose, S. K.; Geetharani, K.; Sahoo, S.; Reddy, K. H. K.; Varghese, B.; Jemmis, E. D.; Ghosh, S. Synthesis, Characterization, and Electronic Structure of New Type of Heterometallic Boride Clusters. Inorg. Chem. 2011, 50, 9414 9422. (d) Dhayal, R. S.; Sahoo, S.; Reddy, K. H. K.; Mobin, S. M.; Jemmis, E. D.; Ghosh, S. Vertex-Fused Metallaborane Clusters: Synthesis, Characterization and Electronic Structure of $\left[\left(\eta^{5}-\mathrm{C}_{5} \mathrm{Me}_{5} \mathrm{Mo}\right)_{3} \mathrm{MoB}_{9} \mathrm{H}_{18}\right]$. Inorg. Chem. 2010, 49, 900-904. (e) Bose, S. K.; Geetharani, K.; Varghese, B.; Ghosh, S. Condensed Tantalaborane Clusters: Synthesis and Structures of $\left[(\mathrm{Cp} * \mathrm{Ta})_{2} \mathrm{~B}_{5} \mathrm{H}_{7}\left\{\mathrm{Fe}(\mathrm{CO})_{3}\right\}_{2}\right] \quad$ and $\left[(\mathrm{Cp} * \mathrm{Ta})_{2} \mathrm{~B}_{5} \mathrm{H}_{9}\left\{\mathrm{Fe}(\mathrm{CO})_{3}\right\}_{4}\right]$. Inorg. Chem. 2011, 50, 2445-2449.

(12) (a) Ghosh, S.; Lei, X.; Shang, M.; Fehlner, T. P. Role of the Transition Metal in Metallaborane Chemistry. Reactivity of $\left(\mathrm{Cp}^{*} \mathrm{ReH}_{2}\right)_{2} \mathrm{~B}_{4} \mathrm{H}_{4}$ with $\mathrm{BH}_{3}$.thf, $\mathrm{CO}$, and $\mathrm{Co}_{2}(\mathrm{CO})_{8}$. Inorg. Chem. 2000 39, 5373-5382. (b) Ghosh, S.; Beatty, A. M.; Fehlner, T. P. The Reaction of $\mathrm{Cp}^{*} \mathrm{ReH}_{6}, \mathrm{Cp}^{*}=\mathrm{C}_{5} \mathrm{Me}_{5}$, with Monoborane to Yield a Novel Rhenaborane. Synthesis and Characterization of arachno- $\mathrm{Cp}^{*} \mathrm{ReH}_{3} \mathrm{~B}_{3} \mathrm{H}_{8}$ Collect. Czech. Chem. Commun. 2002, 67, 808-812. (c) Ghosh, S.; Noll, B. C.; Fehlner, T. P. Borane Mimics of Classic Organometallic Compounds: $\left[\left(\mathrm{Cp}^{*} \mathrm{Ru}\right) \mathrm{B}_{8} \mathrm{H}_{14}\left(\mathrm{RuCp}^{*}\right)\right]^{0,+}$, Isoelectronic Analogues of Dinuclear Pentalene Complexes. Angew. Chem. Int. Ed. 2005, 44, 65686571.

(13) (a) Ghosh, S.; Noll, B. C.; Fehlner, T. P. Expansion of iridaborane clusters by addition of monoborane. Novel metallaboranes and mechanistic detail. Dalton Trans. 2008, 371-378. (b) Geetharani, K. Bose, S. K.; Pramanik, G.; Saha, T. K.; Ramkumar, V.; Ghosh, S. An Efficient Route to Group 6 and 8 Metallaborane Compounds: Synthesis of arachno- $\left[\mathrm{Cp}^{*} \mathrm{Fe}(\mathrm{CO}) \mathrm{B}_{3} \mathrm{H}_{8}\right]$ and closo- $\left[\left(\mathrm{Cp}^{*} \mathrm{M}_{2}{ }_{2} \mathrm{~B}_{5} \mathrm{H}_{9}\right](\mathrm{M}=\mathrm{Mo}, \mathrm{W})\right.$ Eur. J. Inorg. Chem. 2009, 1483-1487.

(14) Barik, S. K.; Chowdhury, M. G.; De, S.; Parameswaran, P.; Ghosh, S. Extended Sandwich Molecules Displaying Direct Metal-Metal Bonds. Eur. J. Inorg. Chem. 2016, 4546-4550.

(15) Kar, S.; Bairagi, S.; Saha, K.; Raghavendra, B.; Ghosh, S. Chalcogen stabilized trimetallic clusters: synthesis, structures, and bonding of $\left[\left(\mathrm{Cp}^{*} \mathrm{M}\right)_{3}(\mathrm{E})_{6+\mathrm{m}}(\mathrm{BH})_{\mathrm{n}}\right](\mathrm{M}=\mathrm{Nb}$ or $\mathrm{Ta} ; \mathrm{E}=\mathrm{S}$ or Se; $\mathrm{m}=0$ or 1 or $2 ; \mathrm{n}$ = 0 or 1). Dalton Trans. 2019, 48, 4203-4210.

(16) Roy, D. K.; Bose, S. K.; Anju, R. S.; Ramkumar, V.; Ghosh, S. Synthesis and Structure of Dirhodium Analogue of Octaborane-12 and Decaborane-14. Inorg. Chem. 2012, 51, 10715-10722.

(17) Roy, D. K.; Barik, S. K.; Mondal, B.; Varghese, B.; Ghosh, S. A Novel Heterometallic $\mu_{9}$-Boride Cluster: Synthesis and Structural Characterization of $\left[\left(\eta^{5}-\mathrm{C}_{5} \mathrm{Me}_{5} \mathrm{Rh}\right)_{2}\left\{\mathrm{Co}_{6}(\mathrm{CO})_{12}\right\}(\mu-\mathrm{H})(\mathrm{BH}) \mathrm{B}\right]$. Inorg Chem., 2014, 53, 667-669.

(18) Joseph, B.; Barik, S. K.; Ramalakshmi, R.; Kundu, G.; Roisnel, T.; Dorcet, V.; Ghosh, S. Chemistry of Triple-Decker Sandwich Complexes Containing Four-Membered Open $\mathrm{B}_{2} \mathrm{E}_{2}$ Ring ( $\mathrm{E}=\mathrm{S}$ or Se). Eur. J. Inorg. Chem. 2018, 2045-2053.

(19) According to PSEP theory icosahedron [ $14 \times 4$ (8 transition metals $)+4 \times 8$ ( 8 main group elements $)+2=90]+$ triangle $[16 \times 3(3$ transition metals $)=48]$ - edge $[16 \times 2(2$ transition metals $)+2=34]=$ 104.

(20) (a) Wade, K. The structural significance of the number of skeletal bonding electron-pairs in carboranes, the higher boranes and borane anions, and various transition-metal carbonyl cluster compounds. J. Chem. Soc. D 1971, 0, 792-793. (b) Wade, K. Structural and Bonding Patterns in Cluster Chemistry. Adv. Inorg. Chem. Radiochem. 1976, 18, 1-66. (c) Fox, M. A.; Wade, K. Evolving patterns in boron cluster chemistry. Pure Appl. Chem. 2003, 75, 1315-1323.

(21) Mingos, D. M. P. Polyhedral skeletal electron pair approach. Acc. Chem. Res. 1984, 17, 311-319.
(22) King, R. B. Three-Dimensional Aromaticity in Polyhedral Boranes and Related Molecules. Chem. Rev. 2001, 101, 1119-1152.

(23) Kennedy, J. D. In The Borane, Carborane, Carbocation Continuum; J. Casanova Ed.; Wiley Press: New York, 1998; p. 85-116.

(24) Rudolph, R. W.; Pretzer, W. R. Hueckel-type rules and the systematization of borane and heteroborane chemistry. Inorg. Chem 1972, 11, 1974-1978. 
Sequential cluster growth reactions starting from nido-[(Cp*Co $\left.{ }_{2} \mathrm{~B}_{6} \mathrm{Se}_{2} \mathrm{H}_{6}\right]$ to closo- $\left[(\mathrm{Cp} * \mathrm{Co})_{2} \mathrm{~B}_{6} \mathrm{Se}_{2} \mathrm{H}_{6}\left\{\mathrm{Ru}_{3}(\mathrm{CO})_{8}\right\}\right]$

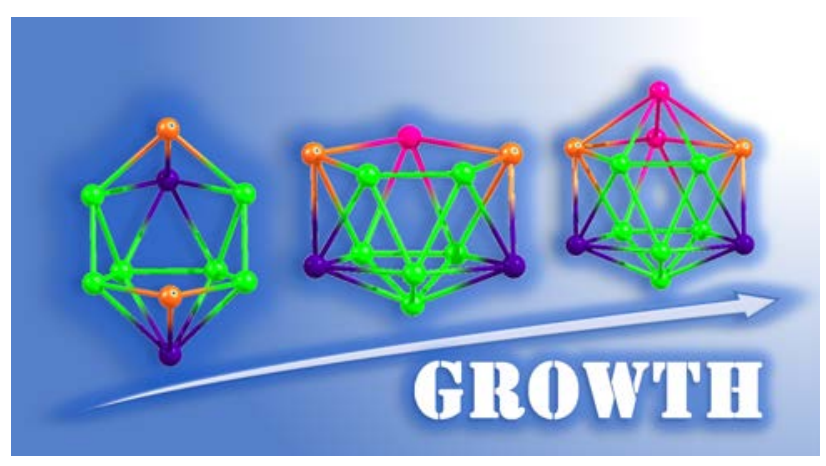

